\title{
Influence of Infill Masonry on a Building Frame Under Seismic Loadings and Its Hazards Vulnerability Assessment
}

\section{Abdul Mannan ${ }^{1}$, Safdar Abbas Zaidi ${ }^{1, *}$, Muhammad Arsalan Saeed ${ }^{2}$ and Farhan Haider ${ }^{2}$}

\author{
'Bauhaus University, Weimar, Germany, Student, MSc-Natural Hazards \& Risks in \\ Structural Engineering, Bauhaus Universität-Weimar, Germany \\ ${ }^{2}$ Lecturer, Department of Civil Engineering, Sir Syed University of Engineering \& \\ Technology-Karachi, Pakistan
}

\begin{abstract}
Article Type: Article
Article Citation: Abdul Mannan, Safdar Abbas Zaidi, Muhammad Arsalan Saeed, Farhan Haider. Influence of infill masonry on a building frame under seismic loadings and its hazards vulnerability assessment. Indian Journal of Science and Technology. 2020; 13(06),617-629.D0l:10.17485/ijst/2020/ v013i06/149873
\end{abstract}

Received date: January 14, 2020

Accepted date: January 23, 2020

*Author for correspondence: Safdar Abbas Zaidi $\nabla$ syed.safdar. abbas.zaidi@uni-weimar.de 9 Bauhaus University, Weimar, Germany

\begin{abstract}
Objectives/methodology: In this study, a four-story frame structure is modelled using finite element software in two different conditions of infill and without infill masonry effects. A pushover analysis is carried out to assess the seismic response and building performance under three different loading conditions of modal, triangular, and uniform loading. The all-possible loadings in negative and positive directions have been applied and building response is measured. A performance capacity curve in terms of base shear is developed for all possible loading scenarios. Finally, a comparison of bare and infill frame has been made and some conclusions were made. Findings/ application: Uniform loading among all three categories is found to be higher in capacity for both types of frames in positive and negative directions. The presence of non-structural masonry walls results in a better behavior of frames compared to bare frame. They initially increase the strength, stiffness, and energy dissipation of frames despite their brittle failure.
\end{abstract}

Keywords: Building Capacity Curve, Performance Point, Infill Frame, Pushover Analysis.

\section{Introduction}

Among all the natural disasters, Earthquake is considered as the most damaging to the ecological and building structures. Construction technologies must be advanced and modified to cope with the hazards of earthquake damages. It is observed that a linear design technique for construction buildings has been failed to the inelastic seismic responses of structures under massive earthquake actions and hence a traditional design approach is no more of importance for the long-term risk and benefits implications [1]. The basic concept of performance-based design is to construct the structure in such a way that should meet all the performance satisfaction under different ground motions and resist the seismic 
hazards as much as possible. This concept is not only limited to buildings but can apply for all the structures and their supported nonstructural elements as well.

In Ref. [2], Ravikumar concluded that several features like stiffness, lateral strength, ductility, and regularity define the behavior of a structure during a seismic activity. This is obvious that failure starts from the weaker points in any natural and un-natural hazard activities. These weaknesses may because of discontinuity in structural mass, stiffness, and geometry [3]. Structures with such discontinuities can be categorized as irregular structures. Irregularities are the most critical reason of failure under lateral loads of earthquakes [4]. In Ref. [5], Furtado et al. observed the impact of proving infill walls in a 15 story RC building and conclude in $20 \%$ increment in its story shear and base shear results. However, in most cases, the influence of infill walls may cause an extensive damage or collapse of structure [6].

\section{Analysis of Frame Structure}

Seismic Analysis is a basic tool of analysis in earthquake engineering used for understanding the response of a building under dynamic excitation [7]. In most of the building codes, equivalent linear static analysis is only recommended for regular and simple structures like small buildings and residential structures. For high-rise buildings, dynamic analyses of time history function and response spectra are suggested [7]. In a research [8], applied non-ductile infill walls at different story levels of 3,6 , and 9 stories in a 9 story building and compared its consequences with simple frames. He found that presence of infill wall results in a brittle failure at 9th story while in simple frame it is found at 3rd story, hence overall, the presence of infill walls increased the strength and reduced the seismic vulnerability of frame [8] a four story building frame is considered with a strong system of upper bound in fill masonry. In addition, a bare frame is analyzed to get the comparison of two models under seismic excitation. The geometrical features of studied building frame are shown in Figure 1. Both frames are considered here without soft story.

The loading pattern for this frame is shown in Figure 2. Loading is applied in a symmetrical manner but the span length is not same for both bays.

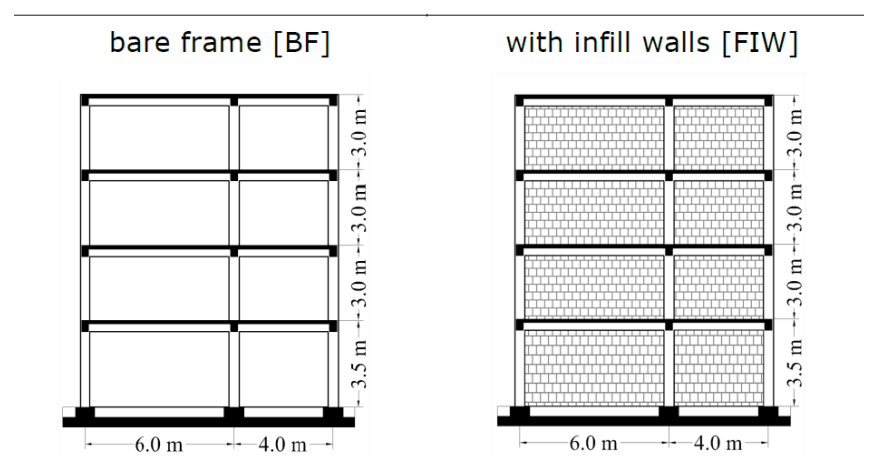

FIGURE 1. Types of frame used in study. 


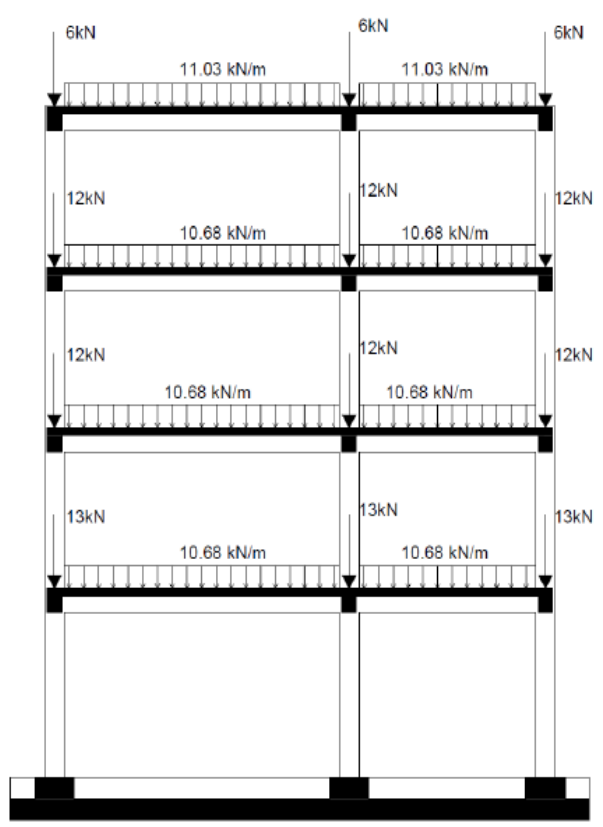

FIGURE 2. Loading pattern on the considered frame.

\subsection{Load Cases}

The following load cases are considered during the analysis of the $2 \mathrm{D}$ frame

I. Modal load pattern (Mode 1)

II. Uniform Load pattern (Application of $1 \mathrm{kN}$ load)

III. Triangular load pattern (Seismic Load pattern based on BCP-2007)

The above load patters are applied in positive $\mathrm{X}(+\mathrm{X})$ and negative $\mathrm{X}(-\mathrm{X})$ directions as the frame is not symmetric. As the frame is $2 \mathrm{D}$ so the analysis is performed only in $\mathrm{X}$ Direction to calculate base shear manually, Euro code 8 and UBC 97 is utilized and results are as under,

Base shear (Euro code $)=449.026 \mathrm{KN}$

Base shear $(\mathrm{UBC})=460.697 \mathrm{KN}$

SAP software is used for all type of analyses and hinges are assigned at beam column joints according to ASCE (seismic evaluation and retrofitting of existing buildings). All hinges are auto assigned using software and the infill is modelled as a diagonal strut which is the most common practice of infill modelling with the tension limit of zero [9-11]. The behavior for the simplicity is taken as of a diagonal compression strut. The properties of the strut are calculated and then manually defined. Figure 3 shows a model for infill struts in SAP

Due to the geometrical non-symmetries in both the base of infill frame, four different diagonal struts are defined manually in the analysis software and description is shown below. Parameters 1 and 3 are for left bay while 2 and 4 are for right bay as shown in Figures 4 and 5. 


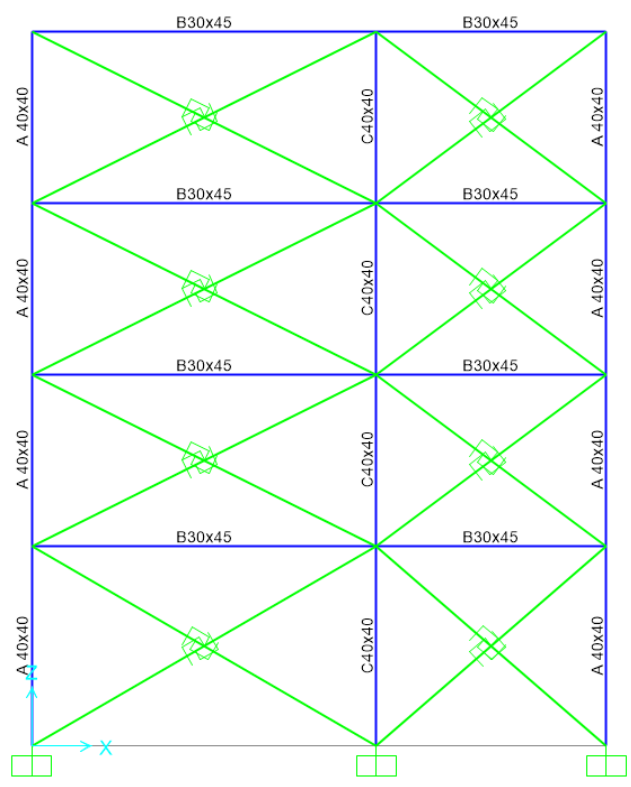

FIGURE 3. Equivalent infill model in SAP.

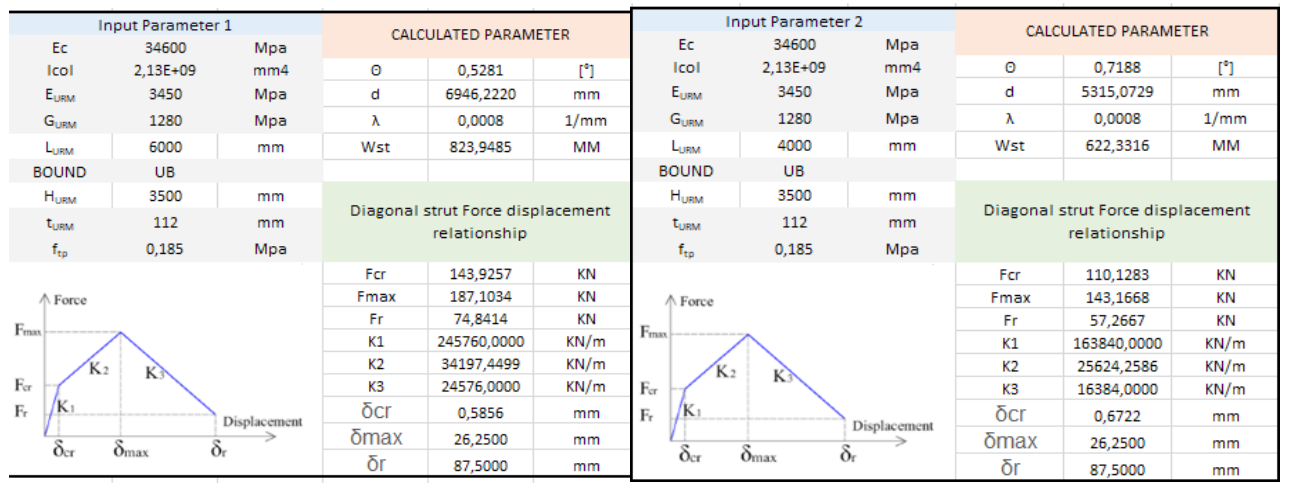

FIGURE 4. Input parameters for 1st story struts.

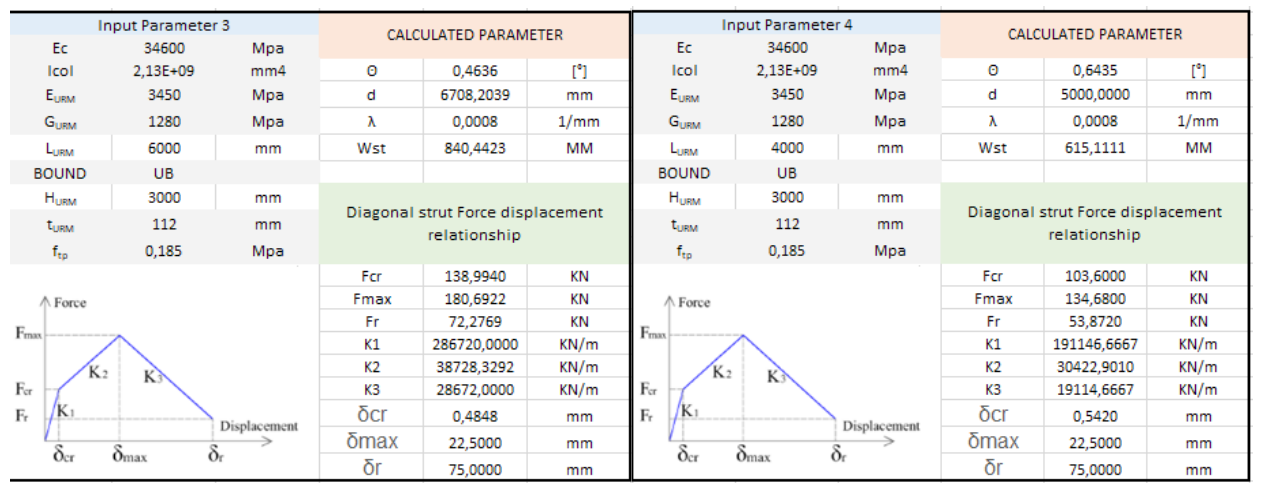

FIGURE 5. Input parameters for other struts. 


\section{Building Capacity and Performance Points}

\subsection{Building Capacity Curve}

The curves in Figure 6 show the capacity curve of the study building. The analysis is performed of $+\mathrm{X}$ and $-\mathrm{X}$ direction with Bare frame and Infill frame.

1) The figure clearly shows that the capacity of Triangular load case and Modal shows the somewhat approximately same trend but uniform load case shows somewhat high capacity.

2) The second conclusion is that the capacity of the infill frame is more as compared to the bare frame as in case of infill the infill act as a diagonal compression strut thus giving the building extra stiffness than bare frame.

\subsection{Building Performance Points}

Tables 1 and 2 show the results of performance point analysis for bare and infill frame, respectively.

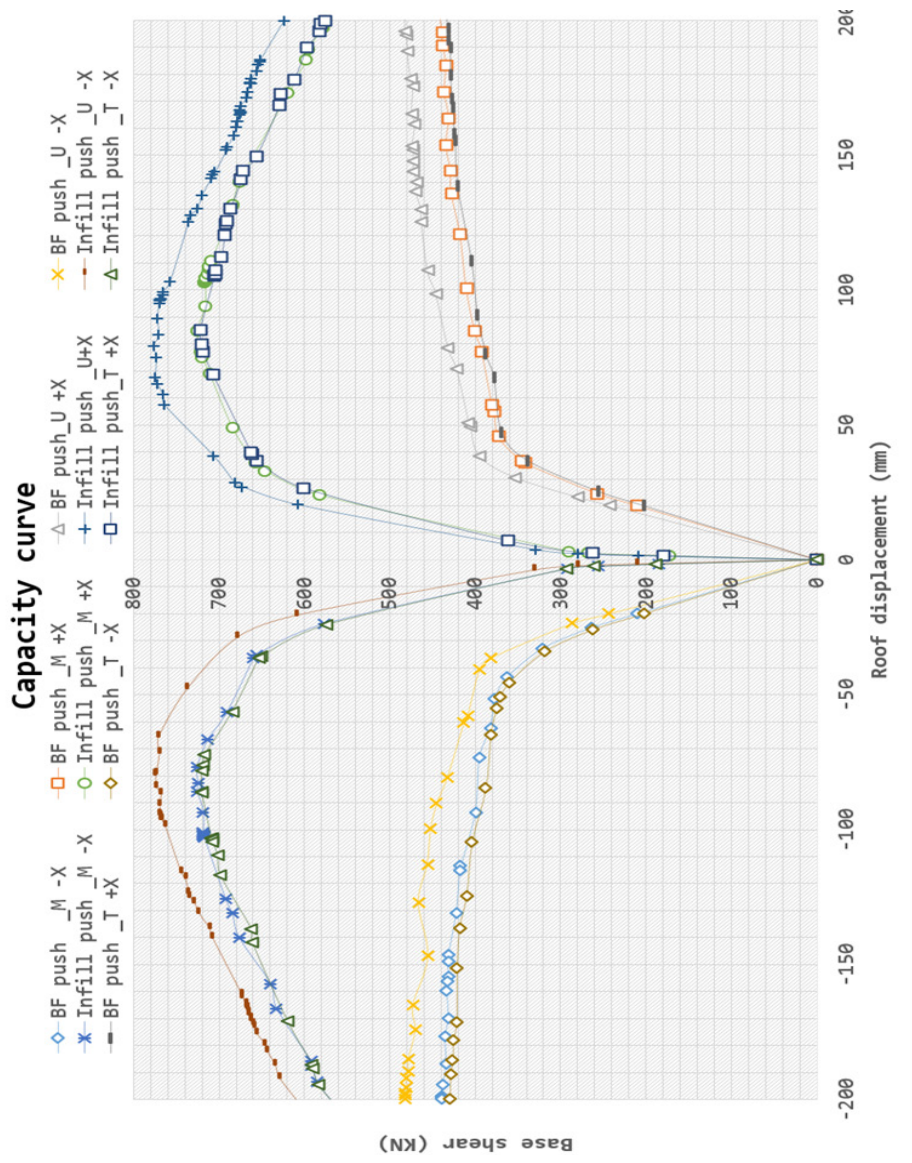

FIGURE 6. Capacity performance curve for all possible load cases. 
where,

$\mathrm{M}+\mathrm{X}$ is modal load in positive $\mathrm{X}$ direction

$\mathrm{M}-\mathrm{X}$ is modal load in negative $\mathrm{X}$ direction

$\mathrm{T}+\mathrm{X}$ is triangular load in positive $\mathrm{X}$ direction

$\mathrm{T}-\mathrm{X}$ is triangular load in negative $\mathrm{X}$ direction

$\mathrm{U}+\mathrm{X}$ is uniform load in positive $\mathrm{X}$ direction

$\mathrm{U}-\mathrm{X}$ is uniform load in negative $\mathrm{X}$ direction

It can be seen from the tabulation (Tables 1 and 2) that uniform loading has a little larger impact on base shear while resulting in a smaller time of vibration. The sample curve for the SAP model result for performance point of U-X infill frame is shown here for understanding (see Figure 7, the intersection of orange and green curve)

The deflected mode shapes for all possible cases are generated from SAP software and are drawn for both bare and infill frames. Their results are displayed in Appendixes A and $\mathrm{B}$, respectively. The performance categories are classified with different colors and labels as shown in Figure 8.

\section{Conclusion}

As from Appendixes A and B, it is clearly concluded that in bare frame almost all of the plastic hinges as well as structural elements yields under seismic actions except in the foundation level which lies in immediate occupancy category. In contrary, infill frame

TABLE 1. Performance point results for bare frame

\begin{tabular}{llcccccr}
\hline $\begin{array}{l}\text { Load } \\
\text { case }\end{array}$ & $\begin{array}{c}\text { Shear } \\
\mathbf{V}(\mathbf{K N})\end{array}$ & $\begin{array}{c}\text { Displace- } \\
\text { ment } \mathbf{D}(\mathbf{m})\end{array}$ & $\begin{array}{c}\text { Spectral } \\
\text { accelera- } \\
\text { tion Sa (g) }\end{array}$ & $\begin{array}{c}\text { Spectral } \\
\text { displacement } \\
\text { Sd (m) }\end{array}$ & $\begin{array}{c}\text { Time } \\
\text { period (s) }\end{array}$ & Ductility & Steps \\
\hline $\mathrm{M}+\mathrm{X}$ & 418.6 & -0.118 & 0.144 & 0.097 & 1.648 & 3.725 & 10,11 \\
$\mathrm{M}-\mathrm{X}$ & 417.05 & 0.119 & 0.143 & 0.098 & 1.661 & 3.679 & 10,11 \\
$\mathrm{~T}+\mathrm{X}$ & 406.8 & 0.115 & 0.14 & 0.094 & 1.637 & 3.484 & 8,9 \\
$\mathrm{~T}-\mathrm{X}$ & 409.2 & -0.121 & 0.141 & 0.099 & 1.679 & 3.696 & 9,10 \\
$\mathrm{U}+\mathrm{X}$ & 457.1 & 0.11 & 0.154 & 0.093 & 1.554 & 3.734 & 10,11 \\
$\mathrm{U}-\mathrm{X}$ & 456.6 & -0.113 & 0.154 & 0.095 & 1.58 & 3.667 & 10,11 \\
\hline
\end{tabular}

TABLE 2. Performance point results for infill frame

\begin{tabular}{llcccccc}
\hline $\begin{array}{l}\text { Load } \\
\text { case }\end{array}$ & $\begin{array}{c}\text { Shear } \\
\mathbf{V}(\mathbf{K N})\end{array}$ & $\begin{array}{c}\text { Displace- } \\
\text { ment } \mathbf{D}(\mathbf{m})\end{array}$ & $\begin{array}{c}\text { Spectral } \\
\text { accelera- } \\
\text { tion Sa (g) }\end{array}$ & $\begin{array}{c}\text { Spectral } \\
\text { displacement } \\
\text { Sd (m) }\end{array}$ & $\begin{array}{c}\text { Time } \\
\text { period (s) }\end{array}$ & Ductility & Steps \\
\hline $\mathrm{M}+\mathrm{X}$ & 683.3 & -0.052 & 0.231 & 0.044 & 0.872 & 15.57 & 6,7 \\
$\mathrm{M}-\mathrm{X}$ & 687.9 & 0.051 & 0.232 & 0.044 & 0.87 & 15.38 & 7,8 \\
$\mathrm{~T}+\mathrm{X}$ & 682.5 & 0.053 & 0.232 & 0.045 & 0.872 & 15.8 & 7,8 \\
$\mathrm{~T}-\mathrm{X}$ & 678 & -0.052 & 0.230 & 0.044 & 0.875 & 15.58 & 6,7 \\
$\mathrm{U}+\mathrm{X}$ & 731.8 & 0.047 & 0.241 & 0.041 & 0.824 & 16 & 7,8 \\
$\mathrm{U}-\mathrm{X}$ & 734.8 & -0.047 & 0.242 & 0.041 & 0.828 & 16.6 & 5,6 \\
\hline
\end{tabular}




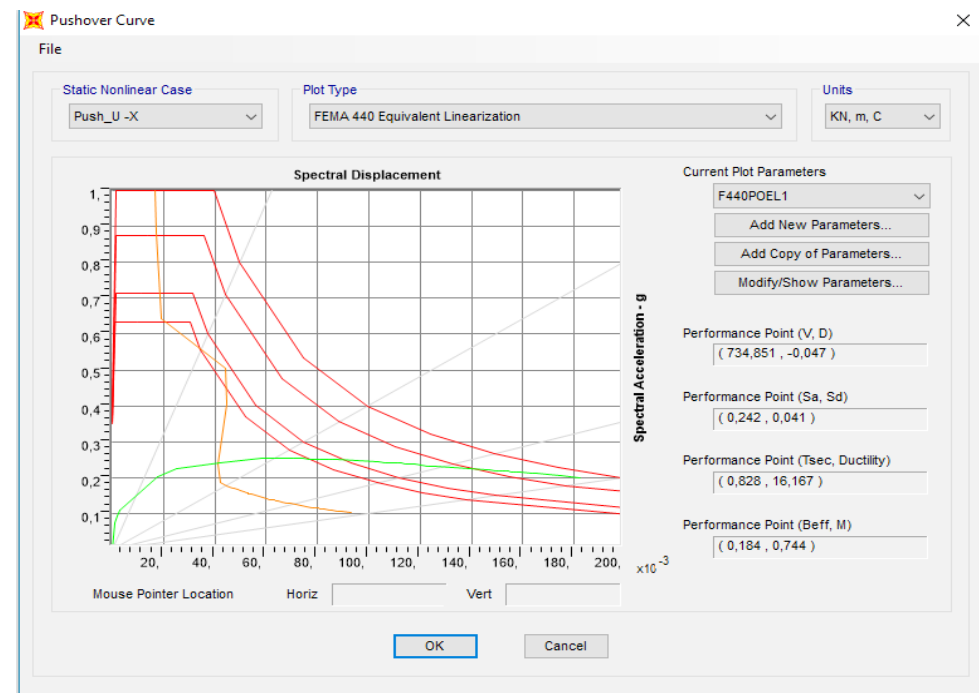

FIGURE 7. Performance point curves for U-X infill frame.

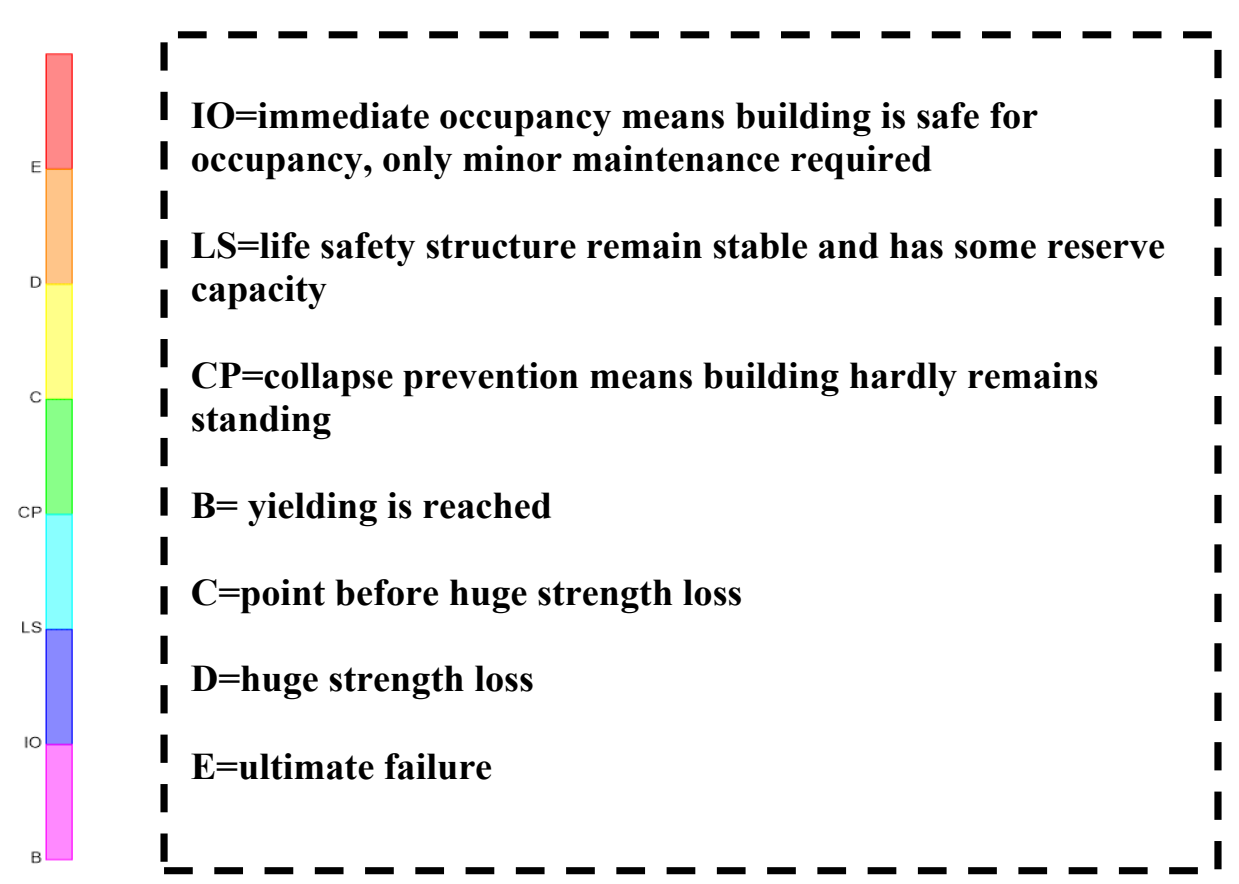

FIGURE 8. Performance categories and their meaning.

shows a better response and a limited number of hinges results in yielding and all the structural elements falling in immediate occupancy category.

1. The capacity analysis result in a conclusion that infill frame structure has more shear capacity in seismic loads compared to simple bare frames 
2. Uniform loading in both the negative and positive direction results in a higher capacity in both frame types.

3. The analysis outcomes indicate that the presence of non-structural masonry infill walls modify the global seismic behaviour of framed structures. They show an increase in initial strength, stiffness and energy dissipation of the in filled frame, compared to bare frame, despite the masonry wall's brittle failure modes.

4. The bare frames in particular are found to be more vulnerable to earthquake-induced collapse. The in-filled frame, due to their larger strength and energy indulgence show a better collapse performance.

5. A more concise and fine research is recommended to assess the impact of infill masonry under nonlinear time history seismic action.

\section{Acknowledgment}

The authors would like to acknowledge all the supports given by Earthquake Damage Analysis Center of Germany throughout the research, also their guidelines and all the facilities for making this study possible.

\section{References}

1. Rajan W. Performance based design and estimation of forces for building frames with earthquake loading. In: International conference on recent trends and challenges in civil engineering at NIT Allahabad, India. 2014. DOI: 10.13140/2.1.2492.3205.

2. Ravikumar C. Effect of irregular configuration on seismic vulnerability of RC buildings. Architecture Research. 2012; 2(3), 20-26. DOI: 10.5923/j.arch.20120203.01.

3. Kumar M, Babu VG. Comparative study of seismic performance of building having mass vertical irregularity at different floor levels. International Journal of Science and Research. 2016; 5(1), 895-899. http://www.sciencepublishinggroup.com/journal/paperinfo.aspx?journalid=22 9\&doi=10.11648/j.ajce.20160403.11

4. Sharma A. Seismic analysis and design of vertically irregular RC building frames. National Institute of Technology Rourkela. 2013; 1-60. http://ethesis.nitrkl.ac.in/5273/1/109CE0062.pdf

5. Furtado A, Vila-Pouca N, Varum H, Arêde A. Study of the seismic response on the Infill masonry walls of a 15-storey reinforced concrete structure in Nepal. Buildings. 2019; 9(39), 1-26. DOI: 10.3390/buildings9020039.

6. Hermanns L, Fraile A, Alarcón E, Álvarez R. Performance of buildings with masonry infill walls during the 2011 Lorca earthquake. Bulletin of Earthquake Engineering. 2014, 12, 1977-1997. https://link.springer.com/article/10.1007/s10518-013-9499-3

7. Ray S, Haque M. Seismic Performance analysis of RCC multi-storied buildings with plan irregularity. American Journal of Civil Engineering. 2016; 4(2), 52-57. DOI: 10.11648/j. ajce.20160403.11.

8. Nurul Amiera Rosman, Sophia C. Alih, Nur Amalina Anuar, Nurul Nabila Fazilan, Nur Hajarul Falahi Abdul Halim, Hossein Shad. Effect of infill panels on the seismic vulnerability of non-ductile reinforced concrete frames. International Journal of Engineering Research and Technology. 2019; 12(8), 1278-1287. http://irphouse.com/ijert19/ijertv12n8_19.pdf 
9. Dolsek M, Fajfar P. The effect of masonry infills on the seismic response of a four-storey reinforced concrete frame-a deterministic assessment. Engineering Structures. 2008; 30(7), 1991-2001. https://doi.org/10.1016/j.engstruct.2008.01.001

10. Furtado A, Rodrigues H, Arêde A, Varum H, Grubišić M, Šipoš TK. Prediction of the earthquake response of a three-storey infilled RC structure. Engineering Structures. 2018; 171, 214-235. https://doi.org/10.1016/j.engstruct.2018.05.054

11. Ricci P, Domineco M, Verderame G. Empirical-based out-of-plane URM infill wall model accounting for the interaction with in-plane demand. Earthquake Engineering \& Structural Dynamics. 2018; 47(3), 802-827. https://doi.org/10.1002/eqe.2992

\section{Building Codes}

1. Uniform Building Code-97

2. EUROCODE-8

3. ASCE 41-13, 2013 Publication Anticipated Seismic Evaluation and Retrofit of Existing Buildings, American Society of Civil Engineers, Reston, Virginia.

4. SAP2000 (2005): Linear and nonlinear static and dynamic analysis and Design of three-dimensional structures. vol. 10. Berkeley (CA): Computers and Structures, Inc.

\section{Appendix-A: Deflected Mode Shapes for Bare Frame}

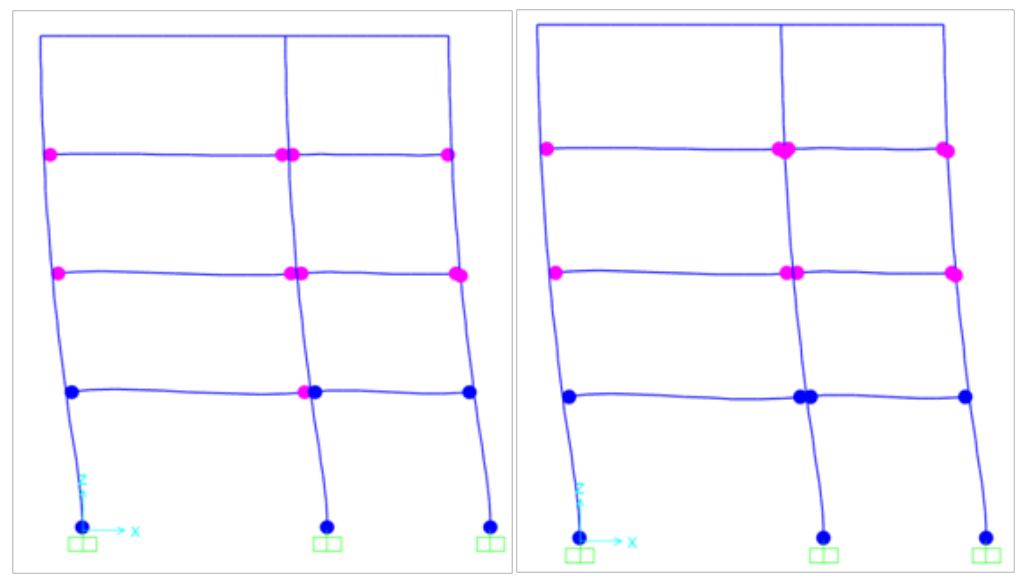

FIGURE A1. Deflected shape at M+X (left) step 10 (right) step 11. 
Influence of Infill Masonry on a Building Frame Under Seismic Loadings and Its Hazards Vulnerability Assessment

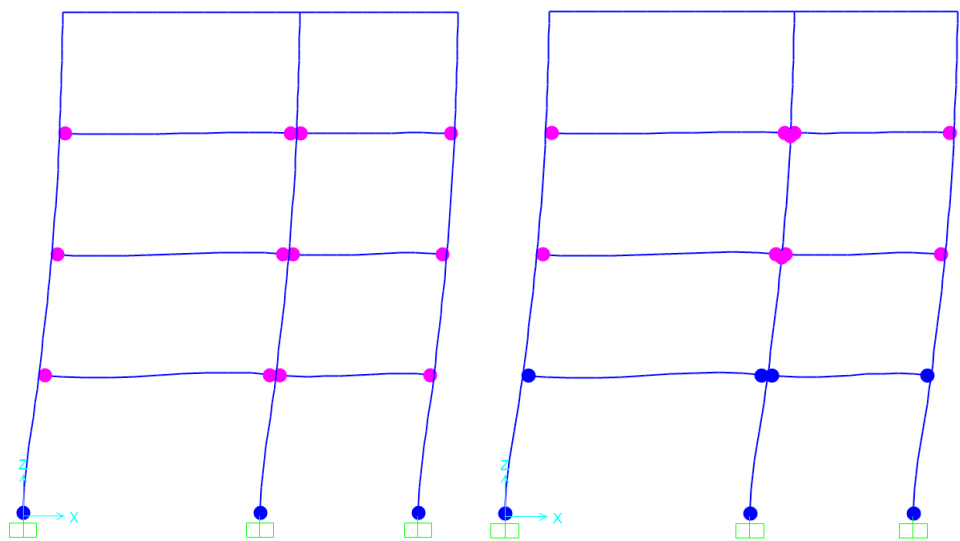

FIGURE A2. Deflected shape at M-X (left) step 10 (right) step 11.

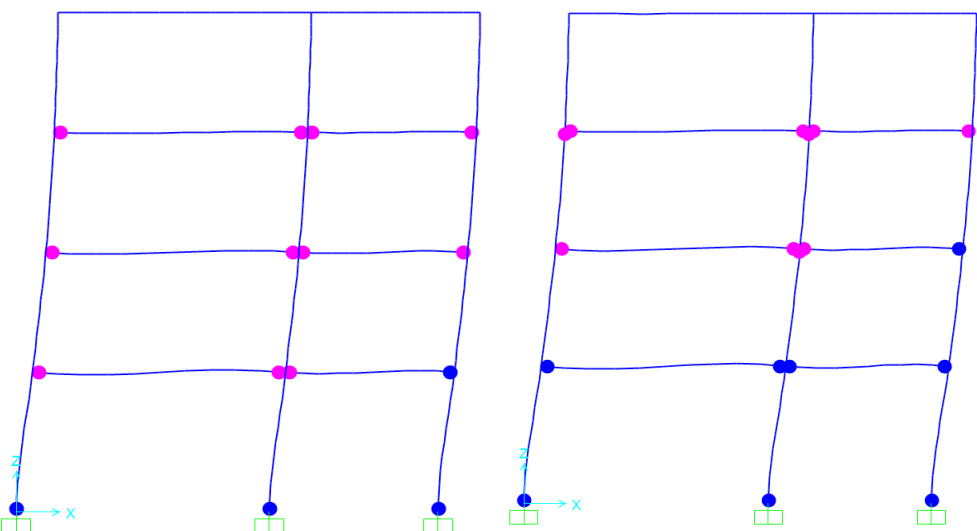

FIGURE A3. Deflected shape at T+X (left) step 8 (right) step 9.
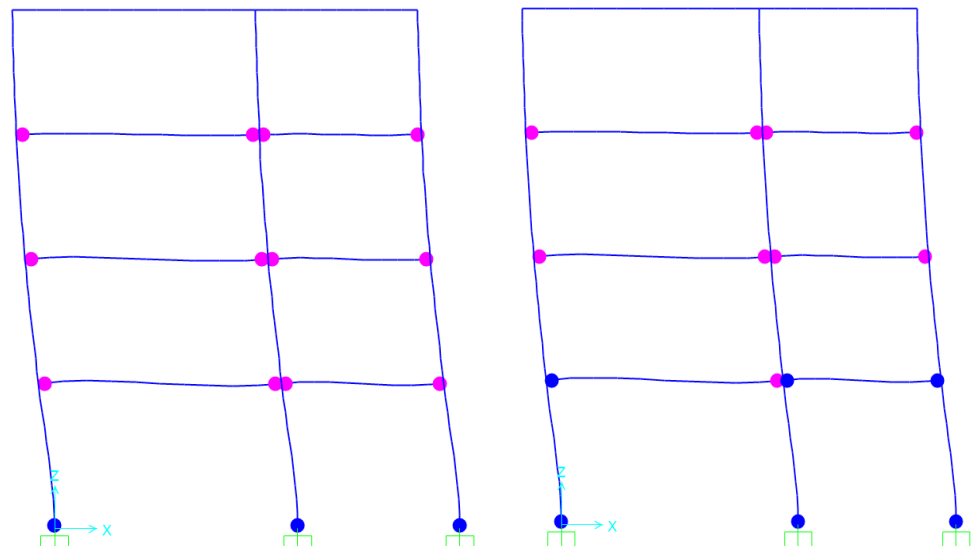

FIGURE A4. Deflected shape at T-X (left) step 9 (right) step 10. 

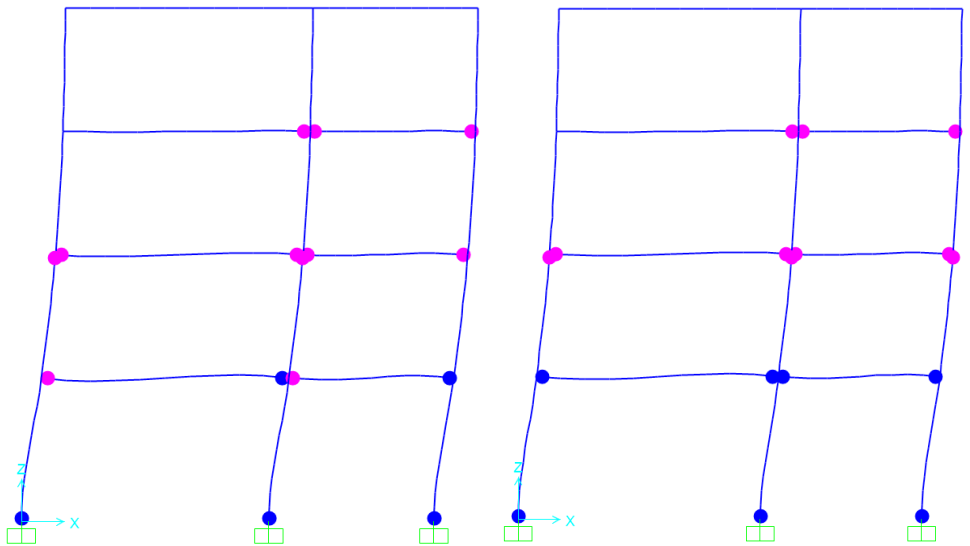

FIGURE A5. Deflected shape at U+X (left) step 10 (right) step 11.
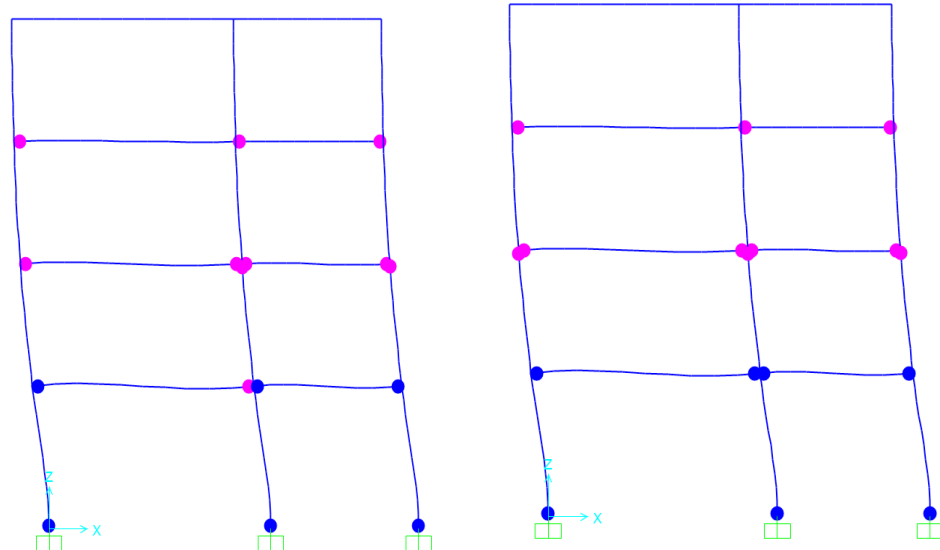

FIGURE A6. Deflected shape at U-X (left) step 10 (right) step 11.

\section{Appendix-B: Deflected Mode Shapes for Infill Frame}
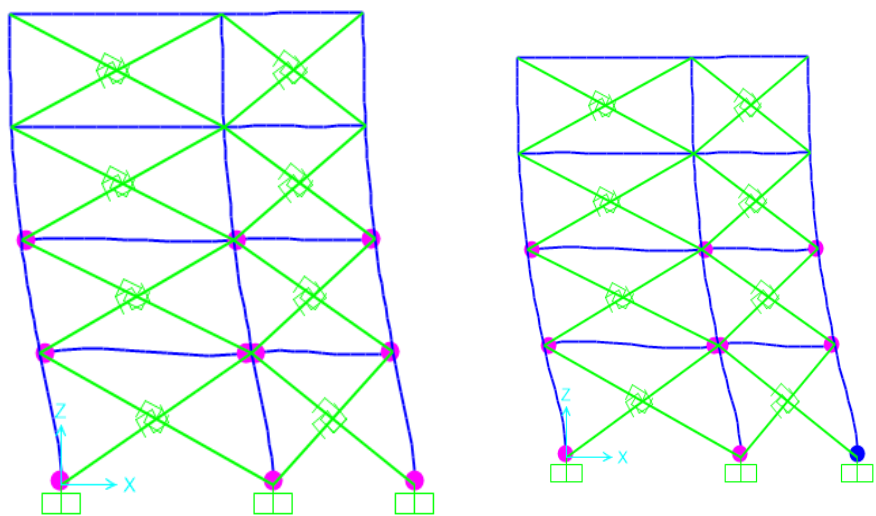

FIGURE B1. Deflected shape at M+X (left) step 6 (right) step 7. 
Influence of Infill Masonry on a Building Frame Under Seismic Loadings and Its Hazards Vulnerability Assessment
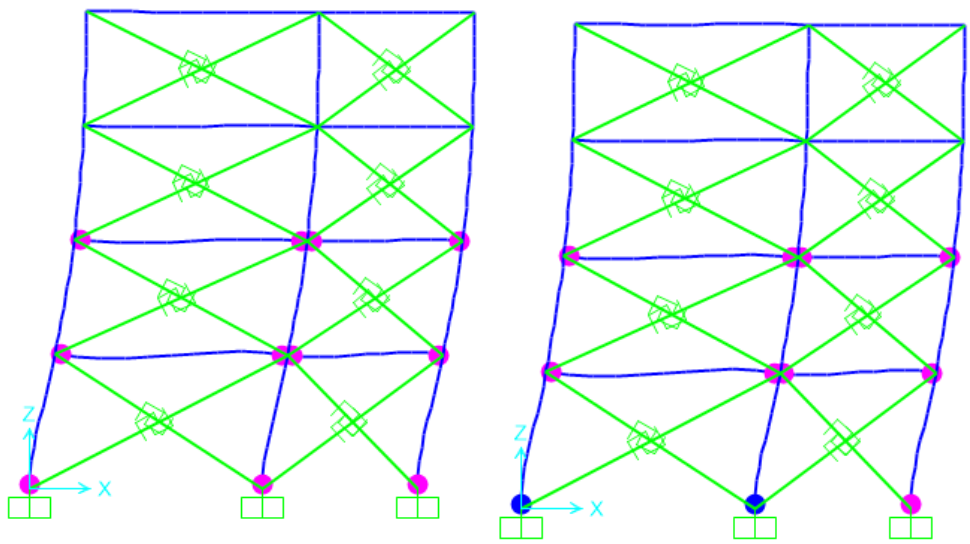

FIGURE B2. Deflected shape at M-X (left) step 7 (right) step 8.
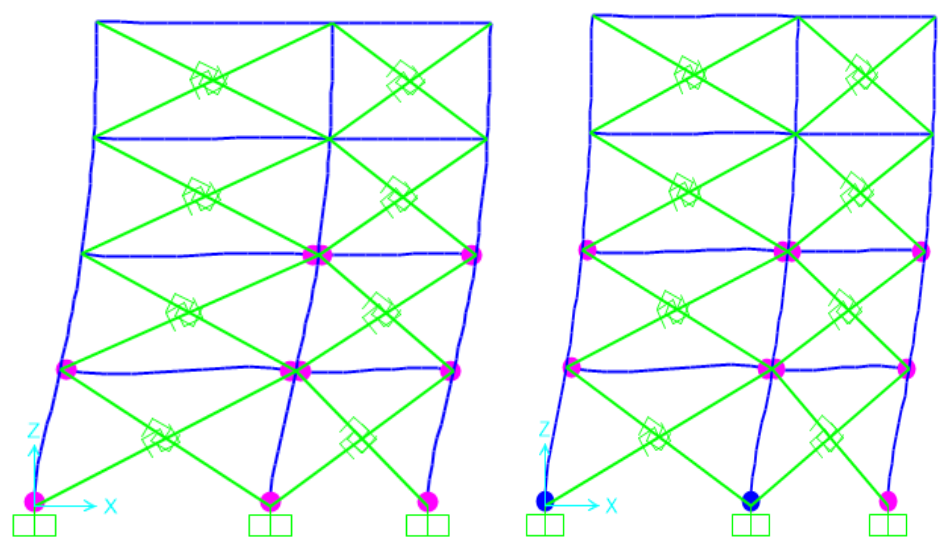

FIGURE B3. Deflected shape at $\mathrm{T}+\mathrm{X}$ (left) step 7 (right) step 8.
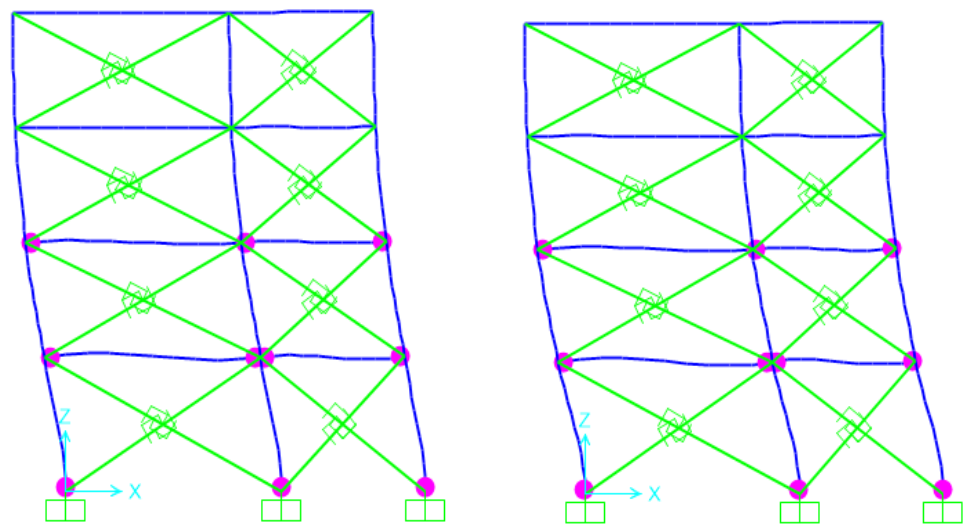

FIGURE B4. Deflected shape at T-X (left) step 6 (right) step 7. 

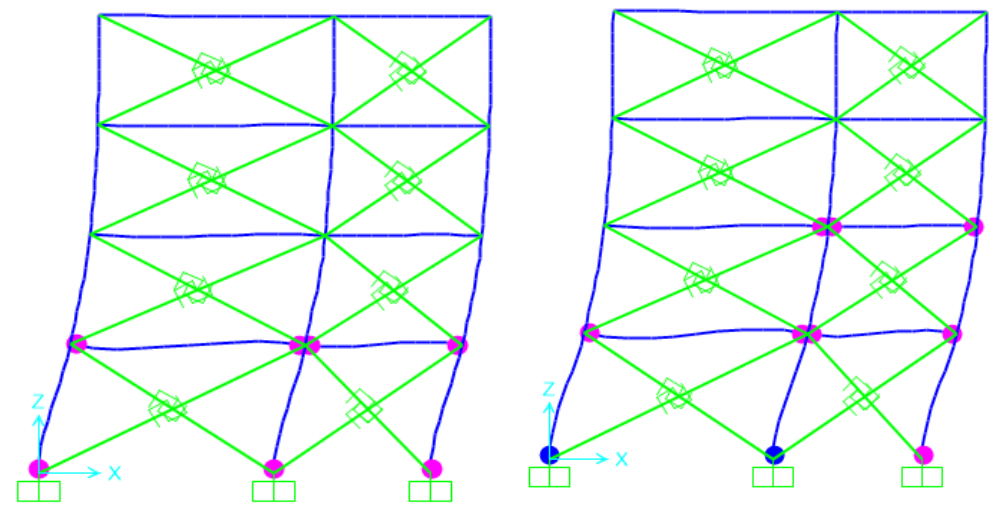

FIGURE B5. Deflected shape at U+X (left) step 7 (right) step 8.
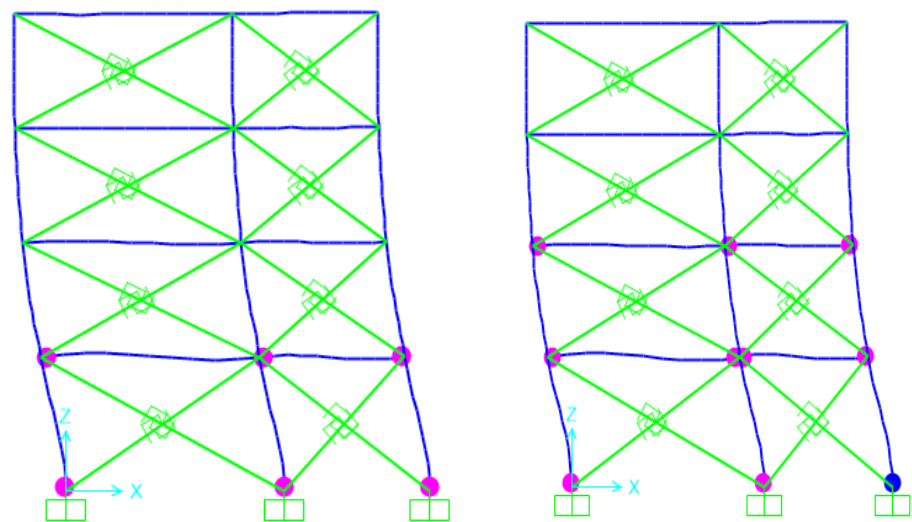

FIGURE B6. Deflected shape at U-X (left) step 5 (right) step 6. 